\title{
EFFECT OF LOCAL APPLICATION OF OVARIAN HORMONES ON THE DELAY IN IMPLANTATION IN LACTATING RATS*
}

\author{
K. YOSHINAGA \\ Laboratory of Veterinary Physiology, Faculty of Agriculture, \\ University of Tokyo, Japan \\ (Received 24th Fune 1960)
}

\begin{abstract}
Summary. The effect of progesterone or oestradiol on the delay in implantation in lactating rats was studied with a new technique for local application. Both progesterone and oestradiol abolish the delay. A localized implantation is induced at the normal time by local application of progesterone at around $5 \mu \mathrm{g}$, but further increase of the dose up to $100 \mu \mathrm{g}$ did not increase the area of the uterus affected by the hormone. On the other hand, in the application of oestradiol, the larger the dose, the larger the region of uterus affected by the hormone, resulting in various degrees of responses from local to systemic positive with increase of dose from 0.002 to $0.1 \mu \mathrm{g}$.

The cause of the delay in implantation during lactation and possible mechanisms are discussed.
\end{abstract}

\section{INTRODUGTION}

It is well known that the implantation of fertilized ova does not take place at the normal time but is delayed for several days in lactating rats and mice. Either progesterone or oestrogen administered by the subcutaneous route has been proved to abolish or shorten the delay (Weichert, 1940; Krehbiel, 1941; Weichert, 1942; Turpeinen, 1947; Bloch, 1948; Morel (cited by Courrier, 1950); Whitten, 1955; Yoshinaga \& Hosi, 1958 a, b).

For further elucidation of the mechanisms involved, local application of ovarian hormones to the uterus seemed to provide the best tool. Canivenc \& Mayer (1955) injected progesterone or oestradiol into the wall of one uterine horn in lactating rats, and induced a localized implantation of ova only in the progesterone-treated region, at the normal time. Due to the delay in implantation in the contralateral horn, so-called superfoetation was obtained in these rats. However, oestrogen thus applied did not induce implantation at the normal time.

Since a method of applying hormones to the uterus without injury is especially desirable when one is concerned with such a delicate phenomenon as implantation, a new method of local application of ovarian hormones was

*Submitted in part fulfilment of the requirements for the degree of Nougaku Hakushi (equivalent to Doctor of Agriculture) at the University of Tokyo. 
worked out, which does not involve tampering with the uterine horn itself. This paper is concerned with the normalizing effect of progesterone or oestradiol on the delay in implantation by the new method.

\section{MATERIALS AND METHODS}

Adult rats of the Wistar strain reared in our laboratory were used. The lactating pregnant rats were prepared as follows: near term, the female was placed in a cage with a male and on the morning following parturition, the vaginal smear was examined microscopically for spermatozoa; if this indicated that mating had occurred, the female with its sucklings were separated from the male and placed in another cage. This day was called the first day of pregnancy. The number of sucklings was adjusted to six.

Hormones were administered on the 5th day. The sucklings were removed from their mother on the 9th day, and the mother was autopsied on the 14th day of pregnancy.

\section{Application of hormones}

On the 5th day of pregnancy when the blastocysts lay free in the uterine lumen, a small incision was made in the dorso-lateral region of the right flank under ether anaesthesia (as a routine, hormones were administered on the right side). With a micro-syringe, an oil solution of progesterone or oestradiol was injected into the adipose tissue surrounding the uterine arteries, close to a diverging point of a blood-vessel tuft which branched from the main uterine artery as shown in Pl. 1, Fig. 1. The needle of the micro-syringe was thrust into the adipose tissue until it reached the desired site, and a given dose of progesterone or oestradiol (dissolved in $1 / 100$ to $1 / 500 \mathrm{ml}$ of rape oil) was injected. The injection was made at only one spot in each animal. Great care must be taken during the whole course of injection not to break any blood vessels nor to allow the needle tip to slip out of the adipose tissue. After withdrawal of the needle, the injected solution could be seen as a droplet close to the neck of the blood-vessel tuft, embedded in adipose tissue, and without any leakage. This injection site could still be clearly distinguished from the white fat as a semi-transparent droplet for a long time, even at autopsy, 9 days after the injection.

In controls, $1 / 250 \mathrm{ml}$ of rape oil alone was injected in the same manner. Four injections were made at different spots along the right uterine horn in animals in this group.

\section{Criteria of response}

On the 14th day of pregnancy, each rat was killed and the size of each implantation swelling was examined macroscopically for response to the hormones administered. In our colony, as already confirmed in a previous report (Yoshinaga, Sekiguchi \& Hosi, 1955), all but $2 \%$ or less of pregnant lactating rats with six sucklings show delay in implantation. This delay is usually 5 days if all the sucklings are removed from the mother on the 9th day of pregnancy. Accordingly, the size of all implantation swellings in the uterus, when examined on the 14th day as in the present study, should correspond to that 


\section{PLATE 1}
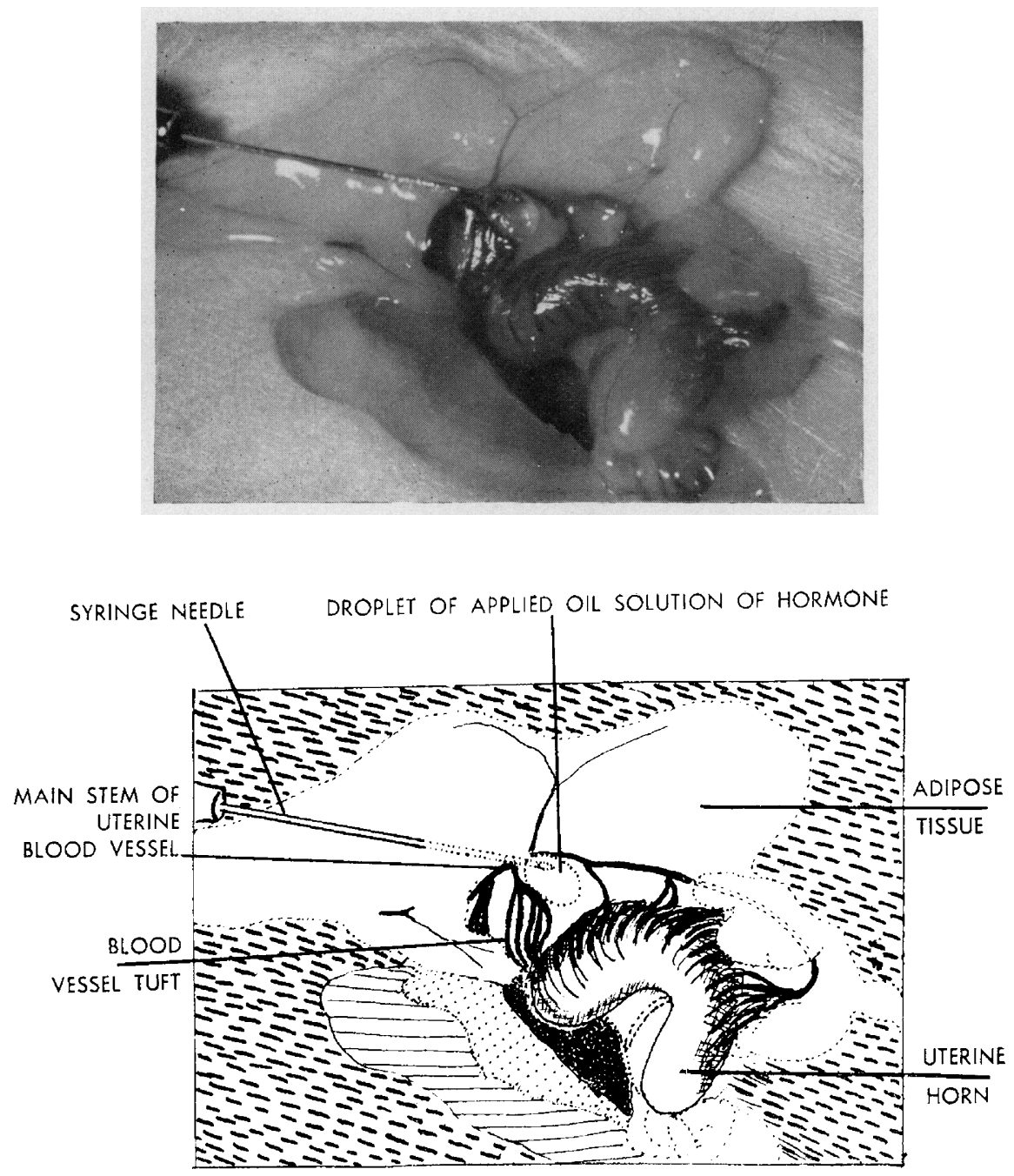

FIG. 1. Technique for local application of hormones. Progesteronc in oil solution $(1 / 250 \mathrm{ml})$ has just been administered to the adipose tissue close to a blood-vcssel tuft. 
PLATE :
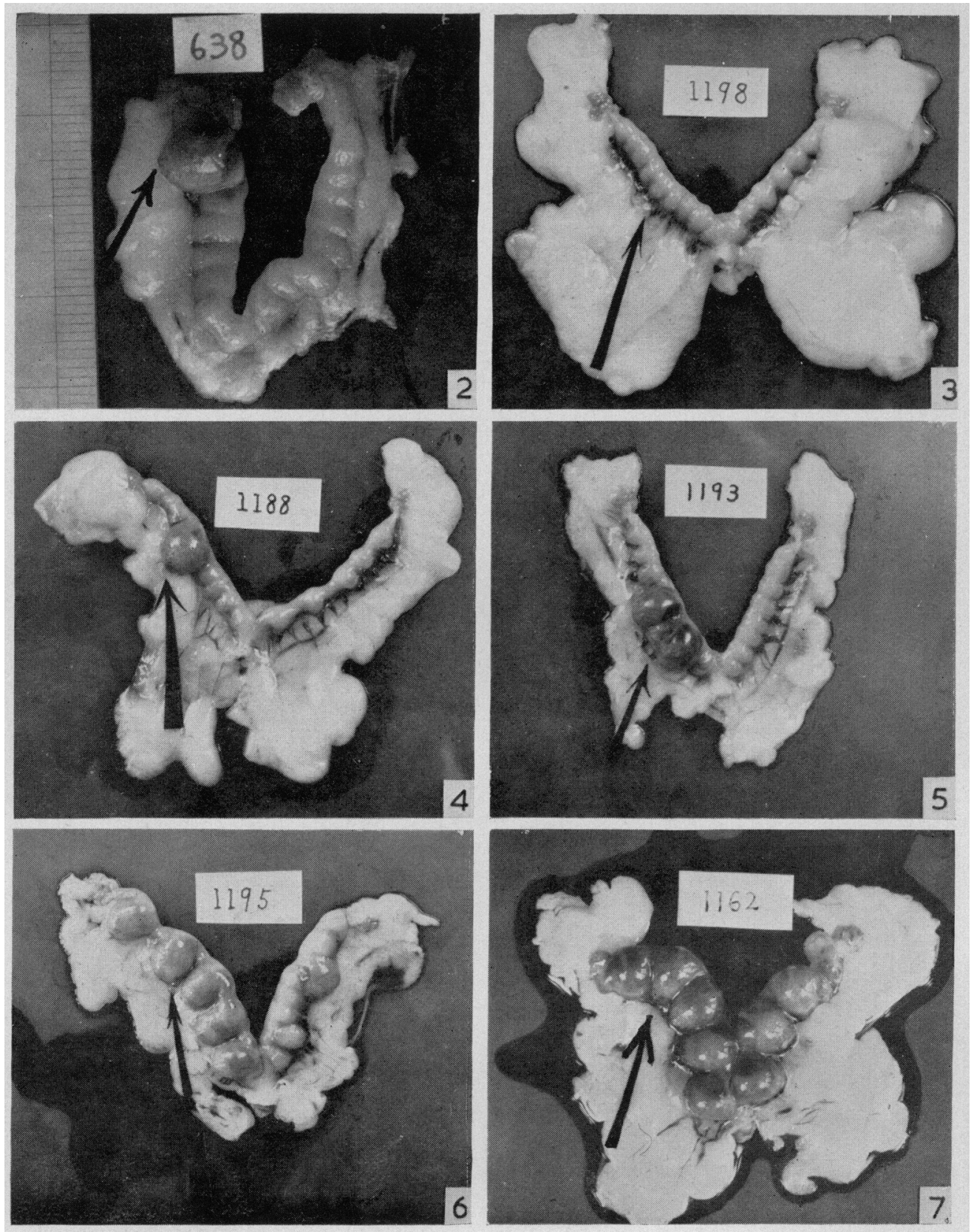

Various reponses obtained by local afplication of ocarian homones. They were administered on the 5th day of a pregnancy concurrent with lactation, sucklings were removed on the 9 th day and the mothers were autopsicel on the 14th day.

Frs. 2. Typical positive response obtained with progesterone $(50 \mu g)$ : a large implantation swelling is found at the treated site corresponding to that of the 14 th day of a normal pregnancy, while other implantation swellings are small and correspond to those of the 9 th day of a normal pregnancy.

Fics. 3 to 7 . Various responses obtained by local application of esestradiol. Arrows indicate application sites. Fis; 3. True negative response (treated with $0.002 \mu \mathrm{g}$ oestradiol). Fici. 4. I cocal positive response (areated with $0.01 \mathrm{\mu g}$ oestradiol). Fic 5 . Spread local positive response (treated with $0.02 \mathrm{\mu g}$ oestradiol). Fir. 6. Incomplete systemic positive response (treated with $0.03 \mathrm{\mu g}$ ocstradiol). Fic. 7 . Systemic positive response (trealed with $0 \cdot 0.5 \mathrm{\mu g}$ oestradiol).

(Facing p. 37: 
of the 9th day of a normal pregnancy, if the treatment did not affect the delay. When the hormone induced nidation at the normal time, one or more large implantation swellings which corresponded to that of the 14th day of the normal pregnancy were found. This was judged to be a positive response.

\section{RESULTS}

\section{EFFECT OF PROGESTERONE}

A typical positive response obtained in experiments with progesterone is shown in Pl. 2, Fig. 2. The size of the implantation swelling found in the part of the uterus supplied by the treated arterial tuft, near to the neck of which progesterone had been injected, corresponded to that of 14th day of pregnancy, while other implantation swellings were small and corresponded to those of the 9th day of pregnancy. In all positive responses except two, only one large swelling could be found in the portion of the uterus nearest to the hormone-containing droplet; the response was thus purely local. In two rats, one with $10 \mu \mathrm{g}$ and the other with $50 \mu \mathrm{g}$ of progesterone, all implantations were large and showed normal development. This type of response was tentatively classified as due to systemic effects with such large doses, but doubt remains. The effective systemic dose for abolition of the delay in implantation by subcutaneous injection is $5 \mathrm{mg}$ daily (Yoshinaga \& Hosi, 1958b). Therefore, these exceptional cases would more likely have been rats that would not have shown delay in implantation without any treatment.

TABLE 1

IMPLANTATION RESPONSE TO LOCAL APPLICATION OF PROGESTERONE

\begin{tabular}{|c|c|c|c|c|c|c|}
\hline \multirow{2}{*}{$\begin{array}{l}\text { Dose } \\
(\mu g)\end{array}$} & \multirow{2}{*}{$\begin{array}{l}\text { No. } \\
\text { rats }\end{array}$} & \multicolumn{2}{|c|}{ Positive response } & \multicolumn{2}{|c|}{ Negative response } & \multirow{2}{*}{$\begin{array}{c}\text { Rate of local } \\
\text { positive } \\
\text { response* }\end{array}$} \\
\hline & & Systemic & Local & True & False & \\
\hline $\begin{array}{c}100 \\
50 \\
30 \\
20 \\
10 \\
5 \\
2 \\
1 \\
0.5 \\
\text { Control }\end{array}$ & $\begin{array}{c}6 \\
7 \\
7 \\
8 \\
11 \\
11 \\
8 \\
7 \\
8 \\
5 \\
\text { (20 spots) }\end{array}$ & $\begin{array}{l}0 \\
1 \\
0 \\
0 \\
1 \\
0 \\
0 \\
0 \\
0 \\
0\end{array}$ & $\begin{array}{l}4 \\
5 \\
6 \\
4 \\
1 \\
5 \\
3 \\
0 \\
0 \\
0\end{array}$ & $\begin{array}{r}1 \\
0 \\
0 \\
0 \\
6 \\
4 \\
4 \\
5 \\
7 \\
19\end{array}$ & $\begin{array}{l}1 \\
1 \\
1 \\
4 \\
3 \\
2 \\
1 \\
2 \\
1 \\
1\end{array}$ & $\begin{array}{r}80 \\
100 \\
100 \\
100 \\
14 \\
56 \\
43 \\
0 \\
0 \\
0\end{array}$ \\
\hline
\end{tabular}

The relation between the dose of progesterone applied locally and the proportion of positive responses is shown in Table 1. Judging from all of the local positive responses, progesterone might exert its action in a very limited area of the uterus. Since progesterone was injected at random at only one spot in each animal, a negative response might well be obtained if free blastocysts in the lumen lay beyond the limit of the hormone effect. From this point of view, the location of the treated tuft of blood vessel relative to implantation sites seemed important in evaluating negative responses. Only if a small 
implantation swelling was seen at the region of the treated tuft, should it be judged as a true negative response. In other negative cases, where no implantation swellings were found at the right place, one cannot judge the response correctly. These were tentatively classified as false negatives and excluded from the evaluation of the positive response rate.

On this basis, as seen in Table 1, local positive responses were obtained in almost all rats receiving more than $20 \mathrm{\mu g}$, but there was no increase in the extent of uterine involvement with increasing dosage of progesterone up to $100 \mu \mathrm{g}$.

As controls, five rats injected with rape oil in four spots along the right uterine horn of each animal showed no positive responses. Examination at each injection spot revealed that all but one were true negative responses and one was a false negative as defined above (see Table 1).

\section{EFFEGT OF OESTRADIOL}

Under the same experimental conditions as with progesterone, various doses of oestradiol were administered in $1 / 250 \mathrm{ml}$ of rape oil. With increasing doses of oestradiol, various degrees of positive response, graded as in Pl. 2, Figs. 4 to 7 , were obtained.

A positive response where only a single large implantation swelling was found at the treated site is called a 'local positive', and that where more than one large implantation swelling was found in the treated horn is called a 'spread local positive'. Cases where the large swellings were found, not only all along the uterus on the treated side, but also in the contralateral uterine horn, together with smaller swellings, are called 'incomplete systemic positives', and those where all implantation swellings were large are called 'systemic positives'.

TABLE 2

IMPLANTATION RESPONSE TO LOGAL APPLICATION OF OESTRADIOL

\begin{tabular}{|c|c|c|c|c|c|c|c|c|}
\hline \multirow{2}{*}{$\begin{array}{c}\text { Dose } \\
\left(10^{-3} \mu g\right)\end{array}$} & \multirow{2}{*}{$\begin{array}{l}\text { No. } \\
\text { rats }\end{array}$} & \multicolumn{4}{|c|}{ Positive response } & \multicolumn{2}{|c|}{$\begin{array}{l}\text { Negative } \\
\text { response }\end{array}$} & \multirow{2}{*}{$\begin{array}{c}\text { Rate of } \\
\text { local positive or } \\
\text { spread local } \\
\text { positive response }\end{array}$} \\
\hline & & Systemic & $\begin{array}{c}\text { Incomplete } \\
\text { systemic }\end{array}$ & $\begin{array}{c}\text { Spread } \\
\text { local }\end{array}$ & Local & True & False & \\
\hline $\begin{array}{r}100 \\
50 \\
40 \\
30 \\
20 \\
10 \\
5 \\
3 \\
2 \\
1\end{array}$ & $\begin{array}{r}7 \\
8 \\
4 \\
10 \\
9 \\
11 \\
5 \\
10 \\
11 \\
6\end{array}$ & $\begin{array}{l}6 \\
6 \\
2 \\
5 \\
1 \\
0 \\
0 \\
0 \\
0 \\
0\end{array}$ & $\begin{array}{l}1 \\
1 \\
2 \\
2 \\
0 \\
0 \\
0 \\
0 \\
0 \\
0\end{array}$ & $\begin{array}{l}0 \\
1 \\
0 \\
2 \\
7 \\
6 \\
1 \\
0 \\
0 \\
0\end{array}$ & $\begin{array}{l}0 \\
0 \\
0 \\
1 \\
1 \\
3 \\
3 \\
2 \\
1 \\
0\end{array}$ & $\begin{array}{l}0 \\
0 \\
0 \\
0 \\
0 \\
0 \\
0 \\
3 \\
6 \\
6\end{array}$ & $\begin{array}{l}0 \\
0 \\
0 \\
0 \\
0 \\
2 \\
1 \\
5 \\
4 \\
0\end{array}$ & $\begin{array}{r}- \\
- \\
- \\
100 \\
100 \\
100 \\
100 \\
40 \\
14 \\
0\end{array}$ \\
\hline
\end{tabular}

* Rate of local positive or spread local positive response $=$ $100 \times$ local or spread local positive cases

(local or spread local positive + true negative cases).

Dose-response relationship is summarized and given in Table 2. All rats showed a negative response (Pl. 2, Fig. 3) with $0.001 \mathrm{ug}$ of oestradiol. A local 
positive response (Pl. 2, Fig. 4) was obtained in three out of four rats with $0.005 \mu \mathrm{g}$, the other showing a spread local response, and the spread local positive (Pl. 2, Fig. 5) was also seen in various rats treated with doses 0.01 to $0.03 \mu \mathrm{g}$. An incomplete systemic positive (Pl. 2, Fig. 6) was obtained in some rats treated with 0.03 to $0.1 \mu \mathrm{g}$, and a systemic positive (Pl. 2, Fig. 7) was seen in almost all rats treated with more than $0.05 \mu \mathrm{g}$ oestradiol. As a characteristic feature for oestradiol, it was found that the larger the dose applied the larger the portion of the uterus affected by the hormone.

\section{DISCUSSION}

Canivenc \& Mayer (1955) administered $250 \mu \mathrm{g}$ of progesterone into the uterine wall on the 3rd day of pregnancy concurrent with lactation, and obtained implantation at the normal time only in the region of the uterine horn where the hormone had been applied. In preliminary studies, we tried intraluminal application of progesterone, but this was considered to be an inadequate technique for the full study of implantation because of traumatization. In the present study, great care was taken not to stimulate the uterus itself. The results of Canivenc \& Mayer are well supported by our new method, and it was clearly shown that if the concentration of progesterone at the response site is increased nidation takes place at the normal time even in lactation. At all dosage levels assayed by this method, up to $100 \mu \mathrm{g}$, except for two cases, progesterone induced only a very localized effect, that is, implantation occurred without delay only in the region supplied by the bloodvessel tuft to which the hormone was applied. If larger amounts of progesterone could be applied by this method, various graded responses from the spread local positive to the systemic positive, would presumably be obtained as with oestradiol. However, solubility of progesterone in the oil used is insufficient for such studies. Since $5 \mathrm{mg}$ daily of progesterone was required for immediate implantation by subcutaneous injection in our rats, the minimum local effective dose would be estimated as less than one hundredth of the systemic effective dose.

Many workers have reported that subcutaneous injections of oestrogen are also effective in abolishing the delay in implantation in the lactating rat, although the mechanism is unknown. That progesterone is indispensable and plays the principal role is demonstrated by the fact that it is effective even after castration. On the other hand, oestrogen alone does not seem to induce implantation; moreover in some experiments it has inhibited it (Courrier \& Raynaud, 1934; Courrier \& Gros, 1935). This has been also clearly supported by our own unpublished data, that if lactating pregnant rats are spayed on the 6th day of pregnancy (a day prior to implantation in our stock), daily subcutaneous injection of oestrone from the day of castration does not induce implantation up to autopsy on the 11 th day of pregnancy, whereas the same treatment is effective for the induction of implantation in the intact animal.

Possible modes of action of oestrogen are that it: (1) stimulates the secretion of progesterone, acting on the ovary, or acting indirectly on the pituitary, or (2) acts synergistically or as a permissive factor directly on the uterus and/or 
the blastocysts. Whitten (1955) has assumed the second possibility, because of lack of obvious ovarian stimulation. Canivenc \& Mayer (1955) have nevertheless failed to induce implantation in lactating rats by local application of $100 \mu \mathrm{g}$ of oestradiol; however, they thought that the ineffectiveness might be due to an excess of the hormone. Strong evidence supporting the second possibility is supplied by the present experiments, in that local action has been demonstrated with very small doses.

It has been confirmed in our lactating rats that single subcutaneous injection of $0.2 \mu \mathrm{g}$ of oestradiol on 5th day of pregnancy abolishes the delay in implantation in all cases, and that 0.05 or $0.1 \mathrm{\mu g}$ of oestradiol is effective for 40 to $80 \%$ of the rats. Thus, the effective dose by subcutaneous injection appears to be comparable with the dose that results in systemic positive response by local application. The minimum effective dose by local application of oestradiol is thus about one-twentieth of the systemic effective or subcutaneous dose.

There is ample evidence that little oestrogen is secreted during lactation in small rodents (Selye, Collip \& Thomson, 1935; Greenwald, 1958). It therefore seems likely that in natural circumstances oestrogen lack is responsible for the delay, intervening as a limiting factor. Whether it acts as a permissive factor, perhaps governing the supply or increase in permeability, or whether it acts in some more chemically synergistic way at the site of action, can only be decided by further work.

\section{ACKNOWLEDGMENTS}

The author wishes to express his gratitude to Professor T. Hosi for his valuable criticism, and to Dr Y. Suzuki for his helpful advice during the preparation of the paper. Grateful thanks are due to Professor C. W. Emmens for his aid in revising the English.

\section{REFERENCES}

BLoch, S. (1948) Zum Problem der Nidationsverzögerung bei der säugenden Maus. Bull. schweiz. Akad med. Wiss. 4, 309.

Ganivenc, R. \& Mayer, G. (1955) Contribution à l'étude expérimentale de la superfétation chez la rate. Recherches basées sur la nidation retardéc. Ann. Endocr., Paris, 16, 1.

Courrier, R. (1950) Interactions between oestrogens and progesterone. Vitam. E Horm. 8, 179.

Courrier, R. \& Gros, G. (1935) Action de la folliculine chez la chatte gestante. C.R. Soc. Biol., Paris, 120,8 .

Courrier, R. \& Raynaud, R. (1934) Expériences d'antagonisme humoral ovarien realisées avec l'étalon international de folliculine cristalisée. C.R. Soc. Biol., Paris, 115, 299.

Greenwald, G. S. (1958) A histological study of the reproductive tract of the lactating mouse. 7 . Endocrin. 17, 17.

Krehbiel, R. H. (1941) The effects of theelin on delayed implantation in the pregnant lactating rat. Anat. Rec. 81, 381.

Selye, H., Collip, J. B. \& Thomson, D. L. (1935) Effect of oestrin on ovaries and adrenals. Proc. Soc. exp. Biol. N.Y. 32, 1377.

Turpeinen, K. (1947) The delayed pregnancy during lactation in the mouse as influenced by certain hormones. Ann. Med. exp. Fenn. 23, 130.

Weichert, G. K. (1940) The experimental shortening of delayed pregnancy in the albino rat. Anat. Rec. 77, 31.

Weichert, C. K. (1942) The experimental control of prolonged pregnancy in the lactating rat by means of estrogen. Anat. Rec. 83, 1.

WhrtTEN, W. K. (1955) Endocrine studies on delayed implantation in lactating mice. F. Endocrin. $13,1$. 
YoshinaGa, K. \& HosI, T. (1958a) On the delayed implantation in the lactating pregnant rat. I. The effect of estrogen. Fap. F. Anim. Reprod. 3, 393. (in Japanese)

YoshinaGA, K. \& Hosi, T. (1958b) On the delayed implantation in the lactating pregnant rat. II. The effect of progesterone. Fap. 7. Anim. Reprod. 4, 107. (in Japanese)

Yoshinaga, K., Sekiguchi, K. \& Hosi, T. (1955) The effect of lactation on the concurrent pregnancy in rats. (Preliminary report.) Fap. F. Anim. Reprod. 1, 107. (in Japanese) 